\section{Development of Molecular Techniques for Studying the Metabolism of Carotenoids in Bixa orellana $\mathbf{L}$.}

\author{
José A. Narváez, Patricia Flores-Pérez, Virginia Herrera-Valencia, \\ Fernando Castillo, Roberto Ku-Cauich, Blondy B. Canto-Canché, \\ Nancy Santana Buzzy, and Renata Rivera-Madrid ${ }^{1}$ \\ Centro de Investigación Científica de Yucatán, Calle 43, No. 130, Col. \\ Chuburná de Hidalgo, 97200 Mérida, Yucatán. México
}

Additional index words. annatto, achiote, bixin, isoprenoids, 3-hydroxy-3-methylglutaryl Co A reductase (HMGR), RNA

\begin{abstract}
The tropical plant Bixa orellana L. (annatto) is the sole source of bixin, the most frequently employed natural pigment in the food industry. Little is known about the physiology, biochemistry, and molecular genetics of this crop. Our purpose was to establish a set of analytical tools that could be applied in the genetic improvement of $B$. orellana, particularly for the screening of characteristics such as bixin content and resistance to diseases or pests. Some preliminary results on the study of carotenoid synthesis are presented. In vitro cultures from several $B$. orellana tissues were established and DNA, RNA, and proteins were extracted from them and analyzed. Similarly, bixin and total carotenoids were quantified.
\end{abstract}

Bixa orellana L. is a perennial tree, native to the tropical Americas, which may have originated in the Amazon basin (Arce, 1999). The seeds of this plant, commonly known as "annatto" ("achiote" in Mexico) have a high content of an orange-red pigment, which consists mainly of the apocarotenoid bixin and has been used for many years as a bread dye and in vegetable oils and drinks (Dendy et al., 1965). Demand for bixin declined considerably when the synthetic Congo Red colorant was introduced. However, as the demand for natural dyes continues to increase, bixin is again being traded in large quantities on the international market. Its economic importance warrants further study of $B$. orellana to obtain crops with greater pigment production, higher disease resistance, and improved agronomic characteristics that will optimize field management. Bixin, the first cis-carotenoid to be isolated from natural sources, is the only one found in $B$. orellana. This 24-carbon compound belongs to the apocarotenoid family, whose members are formed via oxidative degrada-

Received for publications 17 July 2000. Accepted for publication 14 Nov. 2000. We thank QBB Fabiola Escalante for assistance with the HPLC chromatograms, and also thank Drs. F. Vazquez, Richard Cook, and M. Gómez-Lim for their comments on an earlier version of this paper. This research was partially supported by the Consejo Nacional de Ciencia y Technología (CONACyT) through funding for Projects 2201-N9507 and 31602-B, International Foundation for Science (IFS) F 2932-1, and scholarships for J. Narváez (\#9665, CONACyT), V. Herrera, and F. Castillo. The cost of publishing this paper was defrayed in part by the payment of page charges. Under postal regulations, this paper therefore must be hereby marked advertisement solely to indicate this fact.

${ }^{1}$ To whom reprint requests should be addressed. E-mail address: renata@ cicy.mx tion of 40-carbon carotenes. It represents $>80 \%$ of the total carotenoids in the seedcoat and $2 \%$ to $3 \%$ of the total seed weight (Mercadante et al., 1996). The chemical nature of the pigment, as well as that of other isoprenoids present, such as all-E-geranylgeraniol, farnesylacetone, geranylgeranyl octadecanoate, geranylgeranyl foramate, and $\alpha$-tocotrienol, is well known from studies of seed extracts (Jondiko and Pattend 1989; Mercadante et al., 1996). However, little is known about the physiology, biochemistry and molecular biology involved in pigment production. In vitro culture techniques have become a powerful tool for studying basic and applied problems of plant biology (Zenk, 1978). In the last 10 years, these techniques have been utilized for studying gene expression and other biochemical and molecular processes. The objective of our work was to develop several methods for studying gene expression, enzyme regulation, and plant genome organization related to carotenoid accumulation in B. orellana in order to facilitate future study of the carotenoid biosynthesis pathway in this plant.

\section{Materials and Methods}

Explant preparation. Bixa orellana cv. India was used as the source of explants for in vitro cultures. The tested explants came from leaf and stem segments of plantlets germinated in vitro, as well as from cross-sections of immature fruits. Fruit were collected during October and November, which is the fruit production season for $B$. orellana. Seeds were harvested between January and March, stored in darkness at low relative humidity to assure good germination potential, and disinfected by soaking in $70 \%$ ethanol for $15 \mathrm{~min}$, followed by a 3-min rinse in sterile distilled water. They were then washed in a $50 \%$ dilu- tion of commercial bleach (Cloralex ${ }^{\mathrm{TM}}$ at $6 \%$; Allen Co., Puebla, Mexico), followed by three rinses in sterile water. An incision was then made in the seed coat to facilitate germination, and seeds were disinfected again for $7 \mathrm{~min}$ in Cloralex at 6\%. All washes were done using constant agitation under sterile conditions. To stimulate germination after disinfection, seeds were placed in sterile distilled water for $72 \mathrm{~h}$. Finally, they were placed in magenta boxes on solid MS (Murashige and Skoog, 1962) medium, and kept under constant light at 25 to $27^{\circ} \mathrm{C}$. To produce explants, immature fruit were harvested and their external spines removed with a scalpel. The fruit sections were then washed for 3 min with $70 \%$ ethanol, rinsed with sterile distilled water, and submerged for $3 \mathrm{~min}$ in the same disinfectant solution used for the seeds. Finally, they were rinsed four times with sterile distilled water and placed in magenta boxes on MS medium.

Callus induction and maintenance. Explants from the leaves, stem segments and cotyledons of plantlets germinated in vitro were used in callus induction. In all cases, PC basal medium (Phillips and Collins, 1979) was used, with different ratios of 1-naphthaleneacetic acid : 6-benzylaminopurine (NAA : BAP) for each explant type. Explants from leaves and cotyledons were cultivated on 0.54 $\mu \mathrm{M}$ NAA plus $8.88 \mu \mathrm{M}$ BAP. Those from stems were cultivated on $2.68 \mu \mathrm{m}$ NAA plus $4.44 \mu \mathrm{M}$ BAP, and those from immature fruit on 13.43 $\mu \mathrm{M}$ NAA plus $11.09 \mu \mathrm{M}$ BAP. Once callus was formed, it was maintained on medium containing NAA : BAP at a ratio $(\mu \mathrm{M}: \mu \mathrm{M})$ of 0.54 : 8.88 (leaves), $2.68: 4.44$ (stems), or 8.05 : 11.09 (immature fruit). Calli were subcultured every $30 \mathrm{~d}$.

Genomic DNA isolation. The quality of the DNA isolated is critical in molecular genetic studies. The DNA in B. orellana tissues was isolated as described by Rogers and Benedich (1985) and quantified using a DNA Quantification Kit and a VersaFluor Multiple-Wavelength Fluorometer (Bio-Rad Corp., Hercules, Calif.). To verify integrity, samples of nondigested DNA and of DNA digested with EcoRI, EcoRV, and HindIII restriction enzymes were run through electrophoresis in a $1 \%$ agarose gel and stained with ethidium bromide (ETB) to verify integrity.

Isolation of total RNA. Total RNA was extracted using the hot phenol method according to De Vries (1992), and modified by including selective precipitation with urea and $\mathrm{LiCl}$ as proposed by Schuler and Zielinski (1985). Tissue (1 g) was crushed in liquid nitrogen and subsequently resuspended in 20 $\mathrm{mL}$ of a buffer containing $50 \mathrm{~mm}$ Tris- $\mathrm{HCl}$ at $\mathrm{pH}$ 8.5, 10 mм EDTA, $200 \mathrm{~mm} \mathrm{NaCl}$, and 20 $\mathrm{mL}$ of 50 phenol : 49 chloroform : 1 isoamyl alcohol. The mix was incubated for $10 \mathrm{~min}$ at $80{ }^{\circ} \mathrm{C}$ under constant agitation and cooled immediately on ice. The mix was then centrifuged at $8000 g_{\mathrm{n}}$ in a J2-21 centrifuge (Beckman Corp., Palo Alto, Calif.) and the supernatant collected and mixed with one volume of 50 phenol : 49 chloroform : 1 isoamyl alcohol at room temperature. After separating the organic phase by centrifugation, the supernatant 
was collected, one volume of isopropanol was added, and the mixture was precipitated at -20 ${ }^{\circ} \mathrm{C}$ for $30 \mathrm{~min}$, then centrifuged at $8000 g_{\mathrm{n}}$ for $30 \mathrm{~min}$. The pellet was resuspended in $5 \mathrm{~mL}$ TE buffer (Tris-EDTA: $10 \mathrm{~mm}$ Tris $\mathrm{HCl}, \mathrm{pH}$ 7.4, 1 mм EDTA, $\mathrm{pH} 8$ ), and a second precipitation was performed with two volumes of cold absolute ethanol and 0.1 volume of $5 \mathrm{~m}$ $\mathrm{NaCl}$ at $-20{ }^{\circ} \mathrm{C}$ for $30 \mathrm{~min}$, to eliminate the excess phenol. The suspension was centrifuged at $8000 g_{\mathrm{n}}$ for $20 \mathrm{~min}$ and the pellet was resuspended in $0.5 \mathrm{~mL}$ of TE buffer. To remove the DNA, 0.25 volumes of both $8 \mathrm{M}$ urea and $10 \mathrm{M} \mathrm{LiCl}$ were added, the suspension was left for $12 \mathrm{~h}$ at $-20^{\circ} \mathrm{C}$, and then centrifuged at $15,000 \mathrm{~g}_{\mathrm{n}}$ for $30 \mathrm{~min}$ at $4{ }^{\circ} \mathrm{C}$ in an $5417 \mathrm{R}$ Eppendorf centrifuge (Eppendorf Corp., New York, N.Y.). The pellet was then resuspended in $1 \mathrm{~mL}$ of $20 \%$ ethanol and washed with $1 \mathrm{~mL}$ of 49 chloroform : 1 isoamyl alcohol for $5 \mathrm{~min}$ at $3000 g_{n}$ to eliminate polysaccharide traces. The supernatant was incubated with two volumes of cold absolute ethanol and 0.1 volume of $3 \mathrm{M}$ potassium acetate for $20 \mathrm{~min}$ at $20^{\circ} \mathrm{C}$, and then centrifuged again at $15,000 g_{\mathrm{n}}$ for 20 $\min$ at $4{ }^{\circ} \mathrm{C}$. The recovered RNA was resuspended in $0.3 \mathrm{~mL}$ of TE buffer and stored at $-80^{\circ} \mathrm{C}$ for later use. The RNA was quantified using a spectrophotometer at $260 \mathrm{~nm}$ and the integrity was verified by non-denaturing $1 \%$ agarose gel electrophoresis.

Protein determination and HMGR assay. For protein extraction and assay of enzyme activity, samples of callus tissue were collected after $30 \mathrm{~d}$ of culture. Following the methodology proposed by Chappell et al. (1991), $1 \mathrm{~g}$ of the tissue was macerated in liquid nitrogen and homogenized in a buffer with $50 \mathrm{~mm} \mathrm{KCl}, 5 \mathrm{~mm} \mathrm{MgCl}, 250 \mathrm{~mm}$ sucrose, $15 \mathrm{~mm}$ EDTA, $100 \mathrm{~mm} \mathrm{KPO}_{3} \mathrm{pH} 7.5,5 \mathrm{~mm}$ dithiotreitol (DTT), $1 \mathrm{~mm}$ phenyl methyl sulphonyl florure (PMSF) and $7.5 \mathrm{mg} \cdot \mathrm{mL}^{-1}$ leupeptine. To recover the microsomal proteins, the extract was centrifuged at $15,000 g_{\mathrm{n}}$ for $10 \mathrm{~min}$, and the supernatant centrifuged at $100,000 g_{\mathrm{n}}$ for $45 \mathrm{~min}$. The pellet was then resuspended in a solution containing $100 \mathrm{~mm}$ potassium phosphate buffer, $\mathrm{pH} 7.5,20 \%$ glycerol (v/v), 5 mм EDTA, $100 \mathrm{~mm} \mathrm{KPO}_{3} \mathrm{pH} 7.5$, $50 \mathrm{~mm}$ DTT, $1 \mathrm{~mm}$ PMSF, and $7.5 \mathrm{mg} \cdot \mathrm{mL}^{-1}$ leupeptine. Proteins were quantified according to Peterson (1977).

The HMGR activity was quantified by formation of $\left[3-{ }^{14} \mathrm{C}\right]$-mevalonate from $\left[3-{ }^{14} \mathrm{C}\right]-$ hydroxy-methylglutaryl $\mathrm{CoA}$ in a reaction mixture containing $3 \mathrm{~mm} \mathrm{NADPH,} 5$ mM DTT, 700 pmol $\left[3-{ }^{14} \mathrm{C}\right]$-hydroxy-methylglutaryl CoA (0.04 $\mu \mathrm{Ci}$ ) (CFA732; Amersham Corp., Buckinghamshire, England), and microsomal protein $(10-60 \mu \mathrm{g})$ in a final volume of $26 \mathrm{~mL}$. The reaction mixture was incubated for $1 \mathrm{~h}$ at 18 to $20^{\circ} \mathrm{C}$ and the mevalonate produced was separated by lactonization using $5 \mathrm{~mL}$ of mevalonate lactate as carrier. The mix was incubated for $15 \mathrm{~min}$ at $20^{\circ} \mathrm{C}$, and then extracted with $300 \mathrm{~mL}$ of ethyl acetate and 125 $\mathrm{mL}$ of saturated phosphate buffer $\mathrm{pH}$ 7.5. The organic phase, containing the radioactive mevalonate, was recovered and counted by scintillation. Three replicate samples were analyzed for each type of callus.
(A)

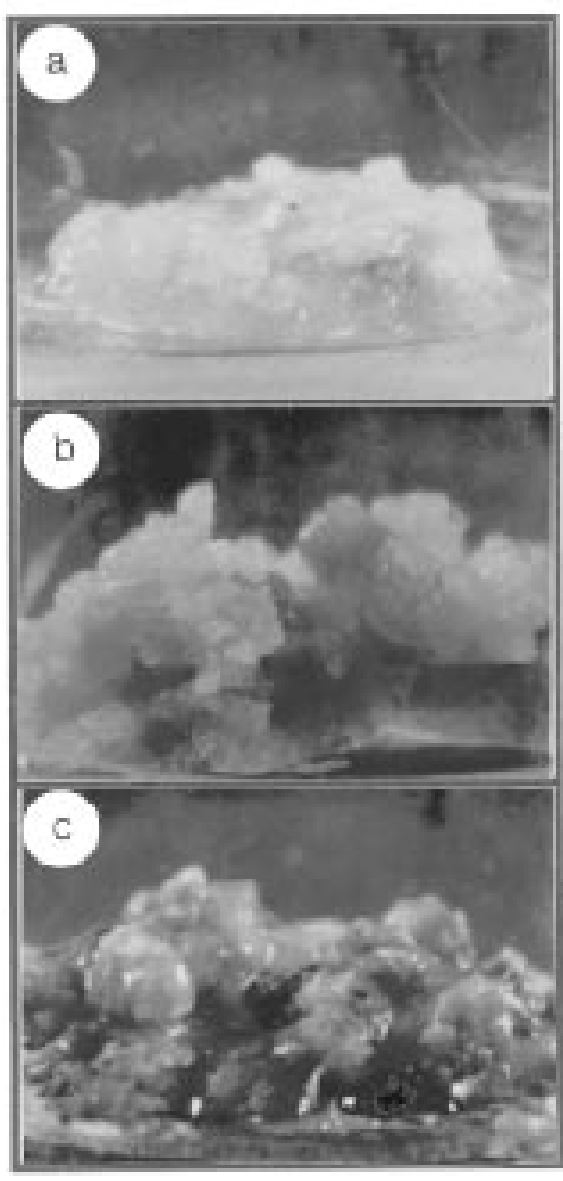

(B)

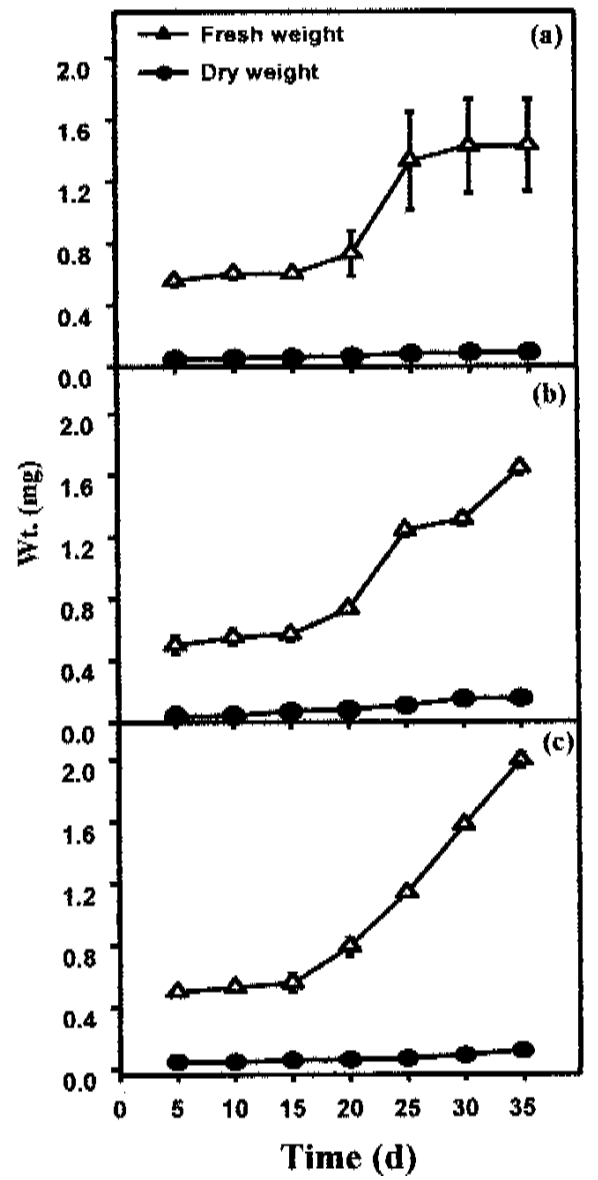

Fig. 1. Callus from B. orellana fruit and plantlet explants obtained using the protocol described in the methods section. (A) Three types of callus produced after $30 \mathrm{~d}$ of culture: (a) white callus from stems; (b) white/brown callus from leaves; (c) brown callus from fruits. (B) Growth curves for the three types of callus tissues.

Carotenoid and bixin quantification. Pigments were extracted and quantified using methodologies standardized for seeds (Brandl, 1988; Lancaster and Lawrence, 1995, 1996; Luf and Brandl, 1988; Rouseff, 1988; Scotter et al., 1994). Vegetative tissues ( $2 \mathrm{~g}$ ) from in vitro cultures were ground to a fine powder and mixed with $2 \mathrm{~mL}$ of 75 acetonitrile : 10 methanol: 15 isopropanol in a Polytron (model T25; Labortechnik, Seelbach, Germany). The resulting slurry was agitated constantly for 45 min in the dark at low temperature, and in a nitrogen atmosphere to eliminate atmospheric oxygen, thereby avoiding carotenoid oxidation and degradation. The suspension was then centrifuged twice at $3000 g_{\mathrm{n}}$ for $20 \mathrm{~min}$. The supernatant was recovered in a fresh tube, dried with nitrogen, and dissolved in $40 \mu \mathrm{L}$ of 75 acetonitrile : 10 methanol : 15 isopropanol. Total carotenoids and bixin were quantified using a DU-65 spectrophotometer (Beckman Corp., Palo Alto, Calif.) with absorbance at 500 and $404 \mathrm{~nm}$, according to McKeown and Mark (1962).

High performance liquid chromatography (HPLC). Callus extracts were subjected to HPLC analysis. After testing several eluants, a solvent mix similar to that used during the extraction was applied at a flow rate of 1.5 $\mathrm{mL} \cdot \mathrm{min}^{-1}$. Samples were injected in a C-18 reverse phase column $(25 \mathrm{~cm}$ long $\times 4.6 \mathrm{~mm}$ i.d.) packed with lichrosoband (model 9679; Alltech, Deerfield, Ill.), and the absorbency was recorded at $493 \mathrm{~nm}$, as described by Biacs and Daood (1994). A bixin standard, purified from annatto seeds based on its $R_{f}(0.72)$ by thin-layer chromatography (TLC) and using the same extraction solvent mix, was used as a control.

\section{Results and Discussion}

Callus culture establishment. Four callus cultures were established from aseptically germinated plantlets or from fruit. Callus formation occurred on several types of explants and tissues. Explants from plantlets exhibited tones from green to light yellow, whereas those from fruit showed a marked tendency to turn rapidly from creamy white to intense brown. Regardless of the explant source, all calli were friable, suggesting that they are suitable for the induction of cell suspension cultures (Fig. 1A). Figure 1B shows the growth dynamic for three more representative lines of callus culture. Cultures were classified into 
Table 1. Quantification of DNA, total RNA, and proteins in different in vitro cultures of B. orellana.

\begin{tabular}{llcc}
\hline \hline Tissues & $\begin{array}{c}\text { Total RNA } \\
\left(\mu \mathrm{g} \cdot \mathrm{mL}^{-1}\right)\end{array}$ & $\begin{array}{c}\text { DNA } \\
\left(\mu \mathrm{g} \cdot \mathrm{mL}^{-1}\right)\end{array}$ & $\begin{array}{c}\text { Proteins } \\
\left(\mu \mathrm{g} \cdot \mathrm{mL}^{-1}\right)\end{array}$ \\
\hline Roots & $300 \pm 75^{\mathrm{z}}$ & $294^{\mathrm{y}}$ & $6.01^{\mathrm{y}}$ \\
Stems & $246 \pm 89$ & $107^{\mathrm{y}}$ & $6.05^{\mathrm{y}}$ \\
Leaves & $181 \pm 42$ & $107^{\mathrm{y}}$ & $7.26^{\mathrm{y}}$ \\
White callus & $121 \pm 1$ & $81 \pm 97$ & $1.19 \pm 0.03$ \\
White/brown callus & $124 \pm 24$ & $35 \pm 38$ & $2.81 \pm 0.41$ \\
Brown callus & $151 \pm 13$ & $529 \pm 371$ & $1.78 \pm 0.060$
\end{tabular}

${ }^{\mathrm{z}} \pm$ Standard deviation, $\mathrm{n}=3$

y One experiment only.

Table 2. Quantification of total carotenes and bixin in different in vitro cultures of $B$. orellana. Leaves, stems, and roots were obtained from 3 -week-old plantlets, and callus cultures were collected at day 30 (i.e., during exponential growth).

\begin{tabular}{lcc}
\hline \hline & $\begin{array}{c}\text { Total } \\
\text { carotenoids } \\
\left(\mathrm{mg} \cdot \mathrm{kg}^{-1}\right)\end{array}$ & $\begin{array}{c}\text { Bixin } \\
\left(\mathrm{mg} \cdot \mathrm{kg}^{-1}\right)\end{array}$ \\
\hline Rissues & $449 \pm 30.4^{\mathrm{z}}$ & $266 \pm 43.2$ \\
Stems & $6,567 \pm 186$ & $4,530 \pm 162.4$ \\
Leaves & $10,526 \pm 251$ & $4,600 \pm 188.9$ \\
White callus & $142 \pm 21.6$ & $9 \pm 25.1$ \\
White/brown callus & $300 \pm 48.2$ & $141 \pm 30.4$ \\
Brown callus & $635 \pm 54.5$ & $400 \pm 46.7$ \\
\hline
\end{tabular}

${ }^{\mathrm{z}} \pm$ Standard deviation, $\mathrm{n}=3$

three types according to phenotype: white callus from stems (Fig. 1Aa), white/brown callus from leaves (Fig. 1Aa), and brown callus from immature fruit (Fig. 1Ac).

The latent period lasted $10 \mathrm{~d}$ for callus obtained from stems, leaves, and fruit. The exponential growth phase, manifested by a considerable increase in the mass of callus, was evident from day 10 onward (Fig. 1B). This phase extended beyond $35 \mathrm{~d}$ of culture, with growth continuing even when media were not changed for long periods (3-4 months). However, the coloration changed after $30 \mathrm{~d}$ of culture. This change was used as a visual marker to select cultures for molecular studies of carotenoid biosynthesis.

The methodologies proposed for the extraction of nucleic acids, proteins, and bixin were optimized for both plantlets and callus cultures. Good yields of nucleic acids were obtained, especially in roots (Table 1). However, the wide variations observed in the plantlet tissues were due to interference by their high polysaccharide contents. Despite this, the RNA isolated from these tissues was suitable to carry out expression studies with different genes, and the DNA isolated was adequate to carry out PCR amplifications as well as for performing Southern blots (Narváez et al., in preparation). Protein yield was lowest in callus tissues. However, the protein obtained were adequate to carry out HMGR enzymatic activity, as shown below. The callus cultures also varied in their capacity to accumulate bixin and other carotenoids (Table 2). Such a trait makes them suitable for the study of genes involved in the carotenoid pathway.

DNA isolation. Total DNA was obtained from seedlings and calluses. Few difficulties were encountered during DNA extraction with these types of cultures, although the DNA isolated from the seedlings and brown callus

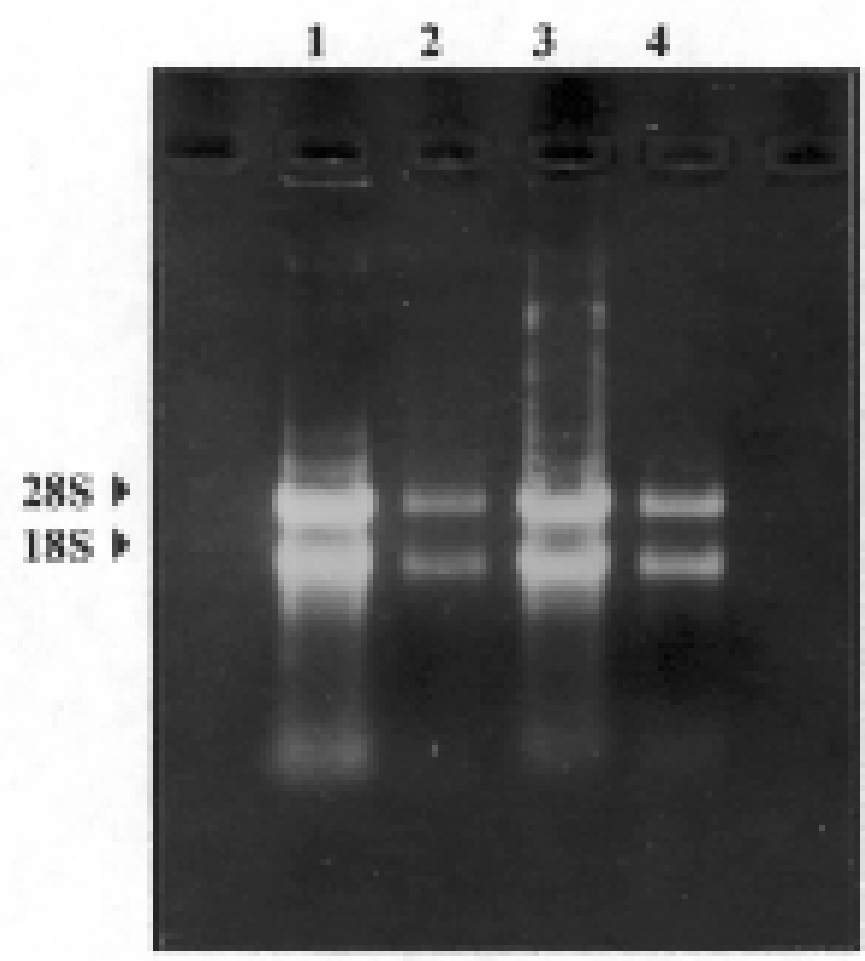

Fig. 2. Electrophoresis of B. orellana RNA in $1 \%$ agarose gel stained with ethidium bromide. The RNA was extracted from $B$. orellana tissues cultured in vitro using the technique described in the methods section. The $18 \mathrm{~S}$ and $28 \mathrm{~S}$ ribosomal bands, characteristic of intact RNA, are visible (arrow). Lane 1, leaves; Lane 2, white/brown callus from leaves; Lane 3, white callus from stems; Lane 4, brown callus from fruit.

tissue was partially contaminated with polysaccharides. Even when the yields were low (Table 1), the extracted DNA was of good quality, and suitable for molecular studies (data not shown).

RNA isolation. Several RNA isolation protocols have been reported using various compounds in the extraction buffer, such as guanidinium thiocyanate (Chomczynski and Sacchi, 1987), hot phenol (De Vreis et al., 1992), and Tris-Borate (López-Gómez and Gomez-Lim, 1992); others, such as that of Schuler and Zielinski (1985), in which urea and $\mathrm{LiCl}$ are used, are based on selective precipitation. However, none of these methods produced $B$. orellana RNA of sufficient quality or quantity. Therefore, we had to develop a better extraction method.

By using the method proposed in this work, high yields (Table 1) of good quality RNA were recovered (Fig. 2). This protocol allows the separation of polysaccharides and DNA from the extracted RNA. The isolated RNA conserved its integrity, shown in Fig. 2. Spectrometry at $260 \mathrm{~nm}$ was used for quantification (Table 1). The high yield (up to $300 \mu \mathrm{g} \cdot \mathrm{mL}^{-1}$ ), and quality of the RNA obtained with this methodology are appropriate for expression studies. The RNA recovered using this method has been used with good results in dot blot, and northern blot tests and RT-PCR (data not shown). Having a reliable method for RNA extraction from $B$. orellana tissues is the first step toward the construction of cDNA libraries.

Protein determination and HMGR assay.
Protein extraction is the key to the study of the enzymes involved in isoprenoid biosynthesis in in vitro cultures of $B$. orellana. A method proposed by Chappell et al., (1991) for Nicotiana tabacum L. was used in the present study for the initial protein extraction from different tissue cultures in vitro, and resulted in high protein yields $\left(1.2-6 \mathrm{mg} \cdot \mathrm{mL}^{-1}\right)$ (Table 1$)$. Because of the high pigment and polysaccharide content of $B$. orellana, centrifugation procedures had to be modified. The protein integrity was verified using an acrylamide native gel, with good results.

To determine whether the isolated proteins were appropriate for enzyme assay, the enzyme HMGR was chosen to begin the biochemical study of $B$. orellana tissues cultured in vitro, since this enzyme is important in isoprenoid synthesis (Bach, 1995; Chappell 1995). The enzymatic activity method was adapted from the technique proposed by Chappell (1991). The HMGR enzyme analysis was done using 30-d cultures, since cultures at this age were at the exponential growth phase, and exhibited color changes (Fig. 1). As a control for this methodology, activity was assayed using leaves, since this tissue has high HMGR activity (Learned and Connolly, 1997; Moore and Oishi, 1993). The activity observed was within the range of 0.75 to 2.7 $\mathrm{pKat} \cdot \mathrm{mg}^{-1}$ Prot in all the tissues. However, no significant differences were found. The leaves had $0.75 \mathrm{pKat} \cdot \mathrm{mg}^{-1}$ Prot and, as it was lower than that observed in callus cultures, this appears to be an efficient method for measuring HMGR activity. However, HGMR activity in 
all tissues remained low, even after $1 \mathrm{~h}$ of incubation. Only small differences were found among callus cultures, despite differences in color, which indicated that these tissues were adequate for analysis of enzymatic activity.

Bixin determination. Different protocols for carotenoid extraction were tested in in vitro cultures. Most of the methods available for bixin quantification have been designed for annatto extracts or for foods colored with this pigment (Lancaster and Lawrence 1995, 1996; Luf and Brandl, 1988; Rouseff, 1988; Scotter et al., 1994). Thus, a protocol for carotenoid extraction from different tissues was developed for the present study by modifying that proposed by Biacs and Daood (1994). Table 2 shows spectrophotometric representations of bixin and carotenoid accumulation according to McKeown and Mark (1962). The level of bixin was good in all the tissues except in white callus from stems. The highest levels of carotenoid and bixin were observed in the plantlet leaves and brown callus from fruit (Table 2).

HPLC analysis in callus culture. Since the spectophotometric quantification was carried out on organic extracts from different $B$. orellana tissues, this assay could be subject to interference from other compounds with similar spectral properties To improve such results, a HPLC protocol was developed for bixin separation from the other pigments present in our callus. After testing various solvent mixtures, the system described by Biacs and Daood (1994) was chosen. Application of this technique to mature seeds allowed the clear resolution of a major peak at 5.95 min, which exactly matched the retention time of the bixin purified by TLC (control). The intensity of such a peak strongly suggests that it corresponds to bixin, since it represents $>80 \%$ of the seed carotenoids, as previously noted (Jodinko and Pattenden, 1989; Lancaster and Lawrence, 1996; Scotter et al., 1994). The HPLC analysis revealed important differences in carotenoid profiles among all the tissues analyzed (Fig. 3). No major peak at the 5- to 7min interval was observed in extracts from callus culture, suggesting the absence of bixin in these tissues. These results confirmed those obtained by spectrophotometer (Table 2). In fact, chromatograms from white calli exhibited barely any peak between 5 and $7 \mathrm{~min}$. This is the first use of HPLC in the separation of carotenoids from non-seed $B$. orellana tissues. In the future, the use of HPLC will facilitate the study of bixin accumulation, as well the analysis of other carotenoids in the tissues.

\section{Conclusions}

In the present study, we developed and adapted a set of methodologies to facilitate research on the pigment-rich plant $B$. orellana, and on bixin, its main pigment. We were able to extract bixin, DNA, RNA, and proteins from various organs of the plantlets and callus produced. In fact, different kinds of callus cultures exhibited different pigment contents, allowing their use in the study of gene and enzyme regulation of carotene production.

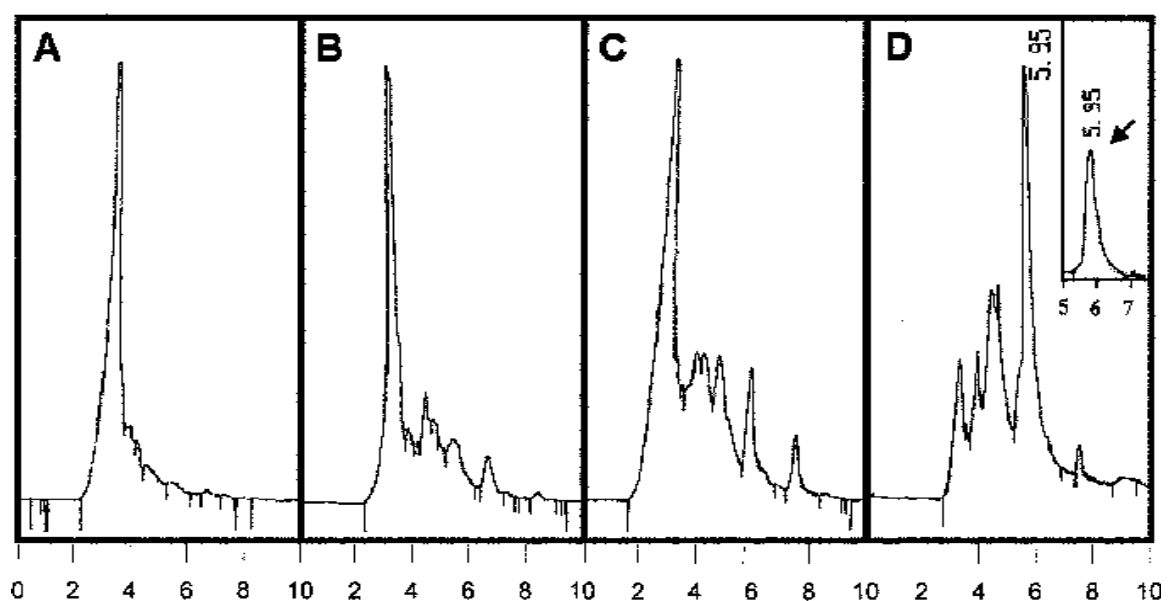

Time (min)

Fig. 3. HPLC chromatograms of carotenoids in $B$. orellana callus tissues. The carotenoids were extracted and the samples analyzed by HPLC as described in the methods section. Samples were collected during the exponential growth stage (day 30): (A) white callus; (B) white/brown callus; (C) brown callus; and (D) seed extracts. Bixin purified for TLC (inside replots) was used as a control for retention time of bixin. Arrow indicates bixin peak. The legend "Time" indicates the exact retention time.

The in vitro cultures provide the additional advantage of ensuring the availability of plant material, regardless of phenological and environmental conditions. Some of the tissues provided good subjects for protein or nucleic acid extractions, although none contained high amounts of bixin. However, according to our results, only leaf tissue had all the necessary characteristics for the study of bixin biosynthesis, since it contains high quantities of bixin.

This set of methodologies can be useful for multiple genetic, molecular genetic, and chemical analyses, and biochemical studies that eventually could lead to a better understanding of the synthesis of these secondary carotenoids, and how these traits, linked to production, are inherited. The protocols should permit the application of any marker in the selection of high bixin-producing plants.

\section{Literature Cited}

Arce, J. 1999. El achiote Bixa orellana L. Cultivo promisorio para el trópico. Earth. 1st ed. Turrialba, Costa Rica.

Bach, T.J. 1995. Some new aspects of isoprenoid biosynthesis in plants-A review.Lipids 30:191202.

Biacs, P.A. and H. Daood. 1994. High-performance liquid chromatography with photodiode array detection of carotenoids and carotenoid esters in fruits and vegetables. J. Plant Physiol. 143:520525.

Chappell, J. 1995. Biochemistry and molecular biology of the isoprenoid biosynthetic pathway in plants. Annu. Rev. Plant Physiol. Plant Mol. Biol. 46:521-547.

Chappell, J., C. Von Lanken, and U. Vögeli. 1991. Elicitor inducible 3-hydroxy-3-methylglutaryl $\mathrm{CoA}$ reductase activity is required for sesquiterpene accumulation in tobacco cell suspension cultures. Plant Physiol. 97:693-698.

Chomczynski, P. and N. Sacchi. 1987. Single-step method of RNA isolation by acid guanidinium thiocynate-phenol-chloroform extraction. Anal. Biochem. 162:156-159.
Dendy, D. 1966. The assay of annatto preparations by thin-layer chromatography. J. Sci. Food Agr. 17:75-76.

De Vries, S., H. Hoge, and T. Biseeing. 1988. Isolation of total and polysomal RNA from plant tissues. Plant Mol. Biol. Manual B6:64-71.

Isler, O., R. Ruegg, and P. Schudel. 1962. Recent progress in the chemistry of natural and synthetic colouring matter and related fields, p. 139. In: T.S Gore, S.V. Sounthankar, and B.D. Tilak (eds.). Academic Press, New York.

Jondiko, I. and G. Pattenden. 1989. Terpenoids and apocarotenoid from seeds of Bixa orellana. Phytochemistry 28:3159-3162.

Lancaster, F.E. and J.F. Lawrence. 1995. Determination of annatto in high-fat dairy products, margarine and hard candy by solvent extraction followed by high-performance liquid chromatography. Food Addit. Contam. 12:9-19

Lancaster, F.E. and J.F. Lawrence. 1996. High performance liquid chromatographic separation of carminic acid and bixin, and norbixin, and the determination of carminic acid in foods. J. Chrom. A. 732:394-398.

Learned, M. and E. Coonolly. 1997. Light modulates the spatial patterns of 3-hydroxy-3-methyl gluataryl Co A reductase gene expression in Arabidopsis thaliana. Plant J. 11:499-511.

López-Gómez, R. and M.A. Gómez-Lim. 1992. A method for extracting intact RNA from fruits rich in polysaccharides using mango mesocarp. HortScience 27:440-442.

Luf, W. and E. Brandl. 1988. Detection of the annatto dye norbixin/bixin in cheese using derivative spectroscopy and high performance liquid chromatography. Z. Lebensm. Unters. Forsch. 4:327-32

McKeown, G. and E. Mark. 1962. Paper chromatography of bixin and related compounds. J. Assoc. Offic. Agr. Chemists 45:761-766.

Mercadante, A.Z., A. Steck, D. Rodríguez-Amaya, H. Pfander, and G. Britton. 1996. Isolation of methyl 9'Z-apo-6'-lycopenoate from Bixa orellana. Phytochemistry 41:1201-1203.

Moore, K.B. and K.K. Oishi. 1993. Characterization of 3-hydroxy-3-methylglutaryl CoA reductase activity during maize seed development, germination, and seedling emergence. Plant Physiol. 101:485-491. 
Murashige, T. and F. Skoog. 1962. A revised medium for rapid growth and bioassays with tobacco tissue cultures. Physiol. Plant. 15:473497.

Peterson, G.L. 1977. A simplification of the protein assay method of Lowry et al. which is more generally applicable. Anal. Biochem. 83:346356.

Phillips, G.C. and G.B. Collins. 1979. In vitro tissue culture of selected legumes and plant regeneration from callus culture of red clover. Crop Sci. 19:59-64.
Preston, H.D. and M.D. Rickard. 1980. Extraction and chemistry of annatto. Food Chem. 5:47-56.

Rogers, A. and L. Benedich. 1985. Extraction of DNA from milligram amounts of fresh, herbarium and mummified plant tissues. Plant Mol. Biol. 5:69-76.

Rouseff, R. 1988. High performance liquid chromatographic separation and spectral characterization of the pigments in turmeric and annatto. J. Food Sci. 53:1823-1826.

Schuler, M. and R. Zielinski. 1989. RNA isolation from light- and dark-grown seedlings, p. 89-96.
In M. Shuler and R. Zielinski (eds.). Methods in plant molecular biology. Academic, New York.

Scotter, M.J., S.A. Thorpe, S.L. Reynolds, L.A Wilson, and P.R. Strutt. 1994. Characterization of the principal coloring components of annatto using high performance liquid chromatography with photodiode-array detection. Food Addit. Contam. 3:301-315.

Zenk, M.H. 1978. The impact of plant tissue culture on industry and agriculture, p. 1-13. In: T.A Thorpe (ed.). Frontiers of plant tissue culture. Univ. of Calgary, Alta. 